\title{
COMPARISON OF SMALL-CLASS VERSUS LARGE-CLASS TUTORIAL DISCUSSIONS
}

\author{
Indah Dewi Ridawati*, Titi Savitri Prihatiningsih**, Widyandana** \\ * Master Student on Nursing, Faculty of Medicine, Universitas Gadjah Mada - Indonesia \\ ** Department of Medical Education, Faculty of Medicine, Universitas Gadjah Mada - Indonesia
}

\begin{abstract}
Background: Not all small tutorial discussion groups discuss national integrated antenatal care. Tutorial discussion in a large class provide discussion together among small discussion groups of the seventh jump. Method: This study was an explanatory design, mixed-methods study. The research sample amounted to 60 students of 2.6 block in the Gadjah Mada University Bachelor Nursing Program and semi-structured interviews conducted on 10 respondents were included in the quantitative study. The data collection conducted on April 14 until June 16 2016. Antenatal knowledge instrument consists 35 multiple choice questions valid and reliable that created on antenatal module. The effect of tutorial measured after day 3 from the treatment time. Nine-eleven student in 3 small tutorial discussion groups in the different room and 30 students in a large tutorial discussion group divided into 3 small discussion groups in the same room got 4 times tutorial in 2 weeks. Materials provided include antenatal delivery.

Results: Based on paired sample $t$ test in get difference the average value of knowledge before and after the tutorial discussion, average increase of knowledge in small tutorial discussion was 0.09 ( $\mathrm{p}=0.93, \mathrm{p}<0.05)$ and $3.62(\mathrm{p}=0.02, \mathrm{p}<0.05)$ in a large tutorial discussion. The qualitative data analysis showed that discussion together among small discussion groups of the seventh jump can increase knowledge acquisition.

Conclusion: The results showed discussion tutorial in a large class more effective increase antenatal care knowledge acquisition than small class.
\end{abstract}

Keywords: tutorial discussion, student, small, large

\begin{abstract}
ABSTRAK
Latar belakang: Beberapa kelompok diskusi tutorial di kelas kecil tidak membahas standar nasional pelayanan antenatal terpadu. Diskusi tutorial di kelas besar memiliki metode pembahasan hasil diskusi semua kelompok kecil pada step ke-7. Metode: Penelitian ini menggunakan desain explanatory, metode mixed method. Jumlah sampel pada penelitian adalah 60 mahasiswa blok 2.6 Program Studi Ilmu Keperawatan Universitas Gadjah Mada dan wawancara semiterstruktur kepada 10 responden yang ikut di dalam penelitian kuantitatif. Pengumpulan data dilakukan dari tanggal 14 April sampai 16 Juni 2016. Instrumen pengetahuan antenatal terdiri dari 35 soal pilihan ganda yang valid dan reliabel yang diambil dari modul antenatal dengan dua skenario yang dibuat peneliti. Efek dari diskusi tutorial diukur 3 hari setelah perlakuan. Tiga puluh mahasiswa terbagi dalam 3 kelompok diskusi tutorial di kelas kecil pada 3 ruangan berbeda dan 30 mahasiswa pada diskusi tutorial di kelas besar terbagi menjadi 3 kelompok tutorial dalam 1 ruangan mendapatkan 4 kali pertemuan tutorial dengan durasi 75-100 menit setiap pertemuan yang diselesaikan dalam waktu dua minggu. Materi berisi pelayanan antenatal.

Hasil: Berdasarkan uji t-test berpasangan perbedaan peningkatan rata-rata pengetahuan sebelum dan sesudah diskusi tutorial di kelas kecil sebesar $0.09(p=0.93, p<0.05)$ dan $3.62(p=0.02, p<0.05)$ pada diskusi tutorial di kelas besar. Data kualitatif menunjukkan bahwa pembahasan bersama hasil diskusi diantara beberapa kelompok diskusi tutorial di kelas kecil dalam satu ruangan pada step ke-7 meningkatkan akuisisi pengetahuan mahasiswa.
\end{abstract}

Contact: indahdewiridawati@gmail.com 
Kesimpulan: Hasil menunjukkan diskusi tutorial di kelas besar lebih efektif meningkatkan akuisisi pengetahuan pelayanan antenatal daripada kelas kecil.

Kata kunci: diskusi tutorial, mahasiswa, kelas kecil, kelas besar

\section{INTRODUCTION}

Indonesia, as a developing country, has worse maternal mortality rate compared to the poorest countries in Asia, such as Bangladesh (170 per 100,000 live births) and Cambodia (170 per 100,000 live births). ${ }^{1}$ Maternal mortality may be prevented by giving antenatal care according to the standard. ${ }^{1}$ Antenatal care itself has not been given according to the standard. ${ }^{2}$ The standard of antenatal care in Indonesia is the integrated antenatal care. ${ }^{3}$

One of the causes why antenatal care is not given according to the standard is due to healthcare providers' lack of knowledge. ${ }^{4}$ Before stored by students, knowledge would have to go through an acquisition process, i.e. receiving or expanding intellectual capability. ${ }^{5}$ One of the factors affecting knowledge acquisition is the learning method. ${ }^{6}$

Antenatal care learning in tutorial discussions in small classes in Nursing School, Faculty of Medicine,
Universitas Gadjah Mada do not focus in giving antenatal care according the neither national nor international standards. The learning outcomes (LOs) and references of the integrated antenatal care are not written in the module of Sexuality and Reproduction. ${ }^{7}$ Several tutorial discussion groups in small classes discuss integrated antenatal care, but a few do not.

Pastrititk ${ }^{8}$ suggested the use of tutorial discussions in large classes as an alternative method in learning nursing. Tutorial discussions in large classes is a tutorial discussion with three smaller classes or more with one or two tutors in a large room and use a scenario as the learning trigger as well as the 7 jumps in the discussion process. ${ }^{9}$ One of the application results of tutorial discussion in large classes is the greater number of references because several groups in a room present and discuss discussion results in the $7^{\text {th }}$ step. ${ }^{8,10}$ 


\section{METHOD}

This was a mix-method study with explanatory design. ${ }^{11}$

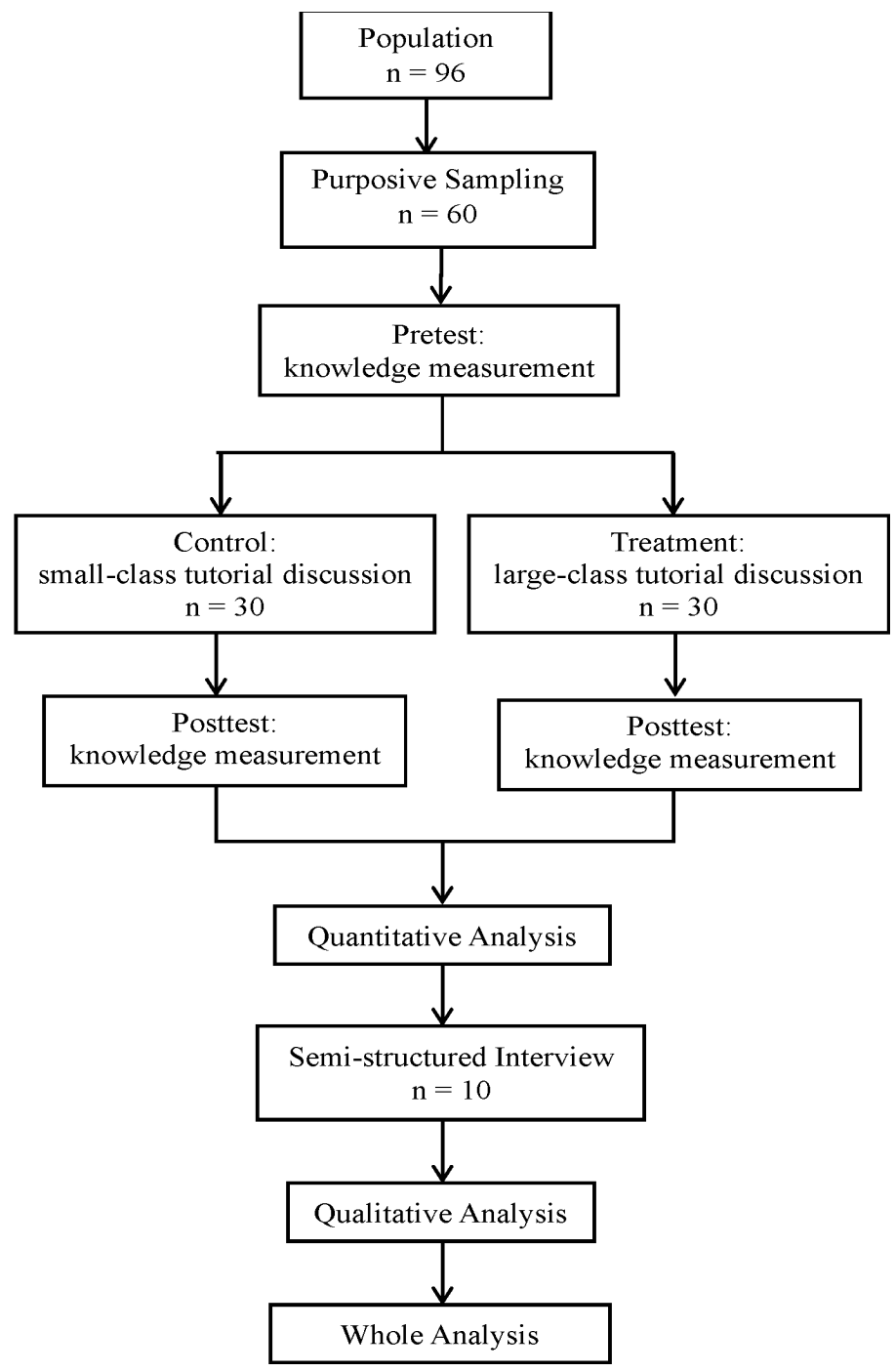

Figure 1. Research Sequence

This study was held in Ismangoen Building, the campus of Nursing School, Faculty of Medicine, Universitas Gadjah Mada, on April 14 $4^{\text {th }}, 2016$ to June $10^{\text {th }}, 2016$.

Tutorial discussion in small classes was held twice a week for one scenario. Tutorial discussion participants in small cases were 9-11 students in each room. The activity in the tutorial discussion used seven jumps.

Tutorial discussion in large classes was held once a week for one scenario. Thirty students, after receiving an orientation, were divided into 3 smaller groups (10 students in each group). Learning process used seven jumps. At the end of the first steps session $\left(1^{\text {st }} 5^{\text {th }}\right.$ step of seven jumps), groups presented the case, learning objectives, and learning issues orally. At the end of the second session, students presented the learning results and answered other groups' questions. The tutor drew conclusions and gave feedbacks in general.

Obtained data were analyzed using univariate analysis. Statistic test used in this study was paired t-tests. 


\section{RESULTS AND DISCUSSION}

\section{Quantitative Results}

Table 1. Pretest-Posttest Comparison in Control and Intervention Groups.

\begin{tabular}{|c|c|c|c|c|c|c|}
\hline \multirow{2}{*}{ Aspect } & \multicolumn{2}{|c|}{ Pre-test Mean } & \multirow{2}{*}{$\mathrm{p}$} & \multicolumn{2}{|c|}{ Post-test Mean } & \multirow{2}{*}{$\mathrm{p}$} \\
\hline & Control & Treatment & & Control & Treatment & \\
\hline Knowledge & 60,10 & 57,71 & 0,23 & 60,19 & 61,33 & 0,57 \\
\hline
\end{tabular}

Table 2. Pretest and Posttest about the Knowledge of Antenatal Care in Control and Intervention Groups.

\begin{tabular}{ccccccc}
\multirow{2}{*}{ Aspect } & \multicolumn{2}{c}{ Control Mean } & \multicolumn{4}{c}{ Treatment Mean } \\
\cline { 5 - 7 } \\
Knowledge & Pre-test & Post-test & $\mathrm{p}$ & Pre-test & Post-test & $\mathrm{p}$ \\
\hline
\end{tabular}

\section{Qualitative Results}

In the intervention group which used tutorial discussion in a large classe, there were 30 students with 1 tutor in 1 classroom. Those thirty students were divided into 3 groups with 10 students in each group. Each group were seated in circles with one whiteboard among the circles. The choosing of the leader, scriber, and co-scriber was done in the early step. The implementation of the $1^{\text {st }}-7^{\text {th }}$ steps of seven jumps was similar with the small classes. The difference was the additional description of learning objectives at the end of the $5^{\text {th }}$ step as well as the presentation and discussion in the three groups altogether in the $7^{\text {th }}$ step. This provided more knowledge sources for students.

"The advantage is that we, err, one group could ask for LOs from the other groups, then we could get more sources. Second, some other group discussed about integrated antenatal care, so we learned and like oh, turns out there's something like that". (R3, R7, R8, R9, R10)

Other result that was obtained from an interview with tutors and students in tutorial discussion in a large class to explore why knowledge in tutorial discussion in a large class increased significantly was because of higher social interaction in tutorial discussion in a large class.

"It's probably like this, Sis, if it's like that then there are 3 groups of us and usually we are separated, then for the same material usually $A$... group $A, B$, and $C$ discussed rather different things. Sometimes, it's like a motivation, well this group has finished, why this other one has not. It's like that, Sis". (R10)

"Large classes, they will express more, they see a group there, a group there, and so the motivation is seen. Ah, there's a small group there, a small group there, so it's like there, ah, whatever the results are". (R3)

Knowledge is included in cognitive aspect. Tutorial discussion is a learning method to increase students' cognitive aspect. In this study, it is concluded that there is a different knowledge acquisition between tutorial discussion in small classes and a large class. Tutorial discussion in a large class is more effective to increase knowledge acquisition and it is seen from the increased score from pretest to posttest. Increased knowledge in tutorial discussion in a large class is higher than increased knowledge in tutorial discussion in small classes. This contradicts with a result by Chris et al. ${ }^{10}$ who concluded that there was not a different knowledge between tutorial discussion in small classes and tutorial discussion in large classes using e-learning. In this study, LOs were not sent via emails to tutors like in a study. ${ }^{10}$ This study used a method by Ting and Danin, ${ }^{9}$ i.e. a representative of each group presented LOs in front of the class using a whiteboard media and was watched by all students and students from different groups might contribute to search for LOs from other groups. 
According to Pembe et $a l,{ }^{12}$ one of the factors affecting antenatal knowledge acquisition was the available medium of knowledge. In tutorial discussion in a large class, each group representative presented and discussed the discussion results together and was listened and watched by other groups in a classroom. This became the medium of knowledge about antenatal care for students in the classroom. The implementation of tutorial discussion altogether in the same classroom in which every discussion process can be seen by other groups might be the medium of knowledge for students in tutorial discussion in a large class. This is in accordance with several studies ${ }^{8-10}$ that one of the results of tutorial discussion learning in a large class was that students had multiple knowledge sources because several groups of students share the knowledge of discussion results in the $7^{\text {th }}$ step in a classroom.

\section{Qualitative Results}

In the intervention group which used tutorial discussion in a large classe, there were 30 students with 1 tutor in 1 classroom. Those thirty students were divided into 3 groups with 10 students in each group. Each group were seated in circles with one whiteboard among the circles. The choosing of the leader, scriber, and co-scriber was done in the early step. The implementation of the $1^{\text {st }}-7^{\text {th }}$ steps of seven jumps was similar with the small classes. The difference was the additional description of learning objectives at the end of the $5^{\text {th }}$ step as well as the presentation and discussion in the three groups altogether in the $7^{\text {th }}$ step. This provided more knowledge sources for students.

"The advantage is that we, err, one group could ask for LOs from the other groups, then we could get more sources. Second, some other group discussed about integrated antenatal care, so we learned and like oh, turns out there's something like that". (R3, R7, R8, R9, R10)

Other result that was obtained from an interview with tutors and students in tutorial discussion in a large class to explore why knowledge in tutorial discussion in a large class increased significantly was because of higher social interaction in tutorial discussion in a large class.
"It's probably like this, Sis, if it's like that then there are 3 groups of us and usually we are separated, then for the same material usually A... group A, B, and C discussed rather different things. Sometimes, it's like a motivation, well this group has finished, why this other one has not. It's like that, Sis". (R10)

"Large classes, they will express more, they see a group there, a group there, and so the motivation is seen. Ah, there's a small group there, a small group there, so it's like there, ah, whatever the results are". (R3)

Knowledge is included in cognitive aspect. Tutorial discussion is a learning method to increase students' cognitive aspect. In this study, it is concluded that there is a different knowledge acquisition between tutorial discussion in small classes and a large class. Tutorial discussion in a large class is more effective to increase knowledge acquisition and it is seen from the increased score from pretest to posttest. Increased knowledge in tutorial discussion in a large class is higher than increased knowledge in tutorial discussion in small classes. This contradicts with a result by Chris et al. ${ }^{10}$ who concluded that there was not a different knowledge between tutorial discussion in small classes and tutorial discussion in large classes using e-learning. In this study, LOs were not sent via emails to tutors like in a study. ${ }^{10}$ This study used a method by Ting and Danin, ${ }^{9}$ i.e. a representative of each group presented LOs in front of the class using a whiteboard media and was watched by all students and students from different groups might contribute to search for LOs from other groups.

According to Pembe et $a 1,{ }^{12}$ one of the factors affecting antenatal knowledge acquisition was the available medium of knowledge. In tutorial discussion in a large class, each group representative presented and discussed the discussion results together and was listened and watched by other groups in a classroom. This became the medium of knowledge about antenatal care for students in the classroom. The implementation of tutorial discussion altogether in the same classroom in which every discussion process can be seen by other groups might be the medium of knowledge for students in tutorial discussion in a large class. This is in accordance with several studies ${ }^{8-10}$ that one of the results of tutorial discussion learning in a 
large class was that students had multiple knowledge sources because several groups of students share the knowledge of discussion results in the $7^{\text {th }}$ step in a classroom.

During a tutorial discussion in a large class, noises were heard during the discussion because groups were discussing simultaneously and it was felt disrupting, but, in fact, those noises were the sources of information which then affected students' knowledge. One of the factors affecting knowledge to acquire antenatal care was the available medium of information. ${ }^{12}$ The more sources of knowledge students have, the higher the knowledge about antenatal care. ${ }^{12}$

Motivation is affected by age, sex, race or ethnics, social economics, personality, medical curriculum followed, teaches, and peers. ${ }^{13}$ Intrinsic motivation affects students more to learn deeply and the results are better than extrinsic motivation. Teachers may help students to increase motivation. ${ }^{14}$ The way to increase intrinsic motivation includes stimulating students to actively participate in learning, giving constructive feedbacks and emotional supports, as well as with warm and positive learning environment. ${ }^{13}$

The number of students in a classroom in a tutorial discussion in a large class is more than the number of students in a tutorial discussion in a small class. The opportunities to have social interaction in tutorial discussion in a large class is bigger than in tutorial discussion in a small class. ${ }^{15}$ The effectiveness of tutorial discussion in a large class is in accordance with Vygotsy's theory called sociocultural theory in cognitive development. Vygotsy complemented Piaget's theory stating that cognitive ability was developed with assimilation and accommodation of new experiences. Vygotsy claimed that there was social and cultural factors in this process. People around the learner might help him/her in learning, such as helping each other to clarify and to organize ideas, giving new understanding and cognitive strategies. Social cognitive theory, according to Bandura, was a new behavior acquired by a learner through seeing and mimicking what has been done by other people. ${ }^{16}$

In this study, the pretest scores in control group was higher compared to treatment group. This is due to the condition during the pretest which was held at the same time with a research lecture because of respondents' tight schedule, so that 60 minutes allocation time was used for a lecture and to answer the pretest. Moreover, this study took samples purposively, so that sampling control was not better than in random sampling. Unlike in the pretest, respondents were conditioned to answer the posttest although it was not held on the same day. Posttest for tutorial discussion in small classes group was held two days before the posttest in the large class.

According to the quantitative and qualitative results, tutorial discussion in a large class may be implemented in campus as one of the alternative methods for learning to increase knowledge. Tutorial discussion in a large class is expected to help students, teachers, and campus in solving problem in the education and learning aspects.

\section{CONCLUSION}

This study points out that there is a different mean antenatal care knowledge acquisition between tutorial discussion in small classes and in a large class. Moreover, tutorial discussion in a large class is more effective to increase antenatal care knowledge acquisition in students compared to tutorial discussion in small classes. At last, the availability of more sources of knowledge and social interaction are factors supporting the effectiveness of tutorial discussion in a large class in increasing students' knowledge acquisition.

\section{REFERENCES}

1. WHO. 2014. Available on http://www.who.com. [accessed 12 Aug 2014]

2. Suryani. Kualitas Pelayanan Antenatal Care di Puskesmas Kota Jambi Tahun 2010. Universitas Gadjah Mada; 2011.

3. Kemenkes RI. Pedoman Pelayanan Antenatal Terpadu. Jakarta: Kemenkes RI; 2010.

4. Astuti et al. Gambaran Pelaksanaan Pelayanan Kebidanan pada Penanganan Bayi Baru Lahir oleh Bidan Delima di Kabupaten Bantul Yogyakarta Tahun 2008. Jurnal Kebidanan dan Keperawatan. 2008;4: 75-84.

5. Menpen R\&B. Pedoman Pelaksanaan Program Manajemen Pengetahuan (Knowledge Management): Peraturan Menteri Negara Pendayagunaan Aparatur 
Negara dan Reformasi Birokrasi Nomor 14 Tahun 2011.; 2011. Available on http://rb.ristek.go.id [accessed 20 Oct 2015]

6. Notoatmodjo. Promosi Kesehatan Global. Jakarta: PT Rineka Cipta; 2013.

7. Tim Blok. Seksualitas dan Reproduksi Blok 2.3. Yogyakarta: PSIK FK UGM; 2015.

8. Pastritik P. Using Problem-Based Learning in a Large Classroom. Nurse Educ Pract. 2006;6:261-7.

9. Tin L, Qin D. Challenges of Conducting ProblemBased Learning in a Large Class. Chinese Education and Society. 2014;47(3):106-10.

10. Roberts C. The Introduction of large class problembased learning into an undergraduate medical curriculum: an evaluation. Med Teach. 2005;27(6):52733.

11. Sugiyono. Metode Penelitian Kombinasi (Mixed Methods). Bandung: Alfabeth; 2016.
12. Pembe AB, Carlstedt A, Urassa DP, Lindmark G, Nystrom L, Darj E. Quality of antenatal care in rural Tanzania: counseling on pregnancy danger signs. BMC Pregnancy Childbirth. 2010;10(35).

13. Kusurkar RA, Groiset G, Cate OJT. Twelve Tips to Stimulate Intrinsic Motivation in students Through Autonomy-supportive Classroom Teaching Derived From Self-Determination Theory. Med Teach. 2011;33:978-82.

14. Brissette A, Howes D. Motivation in Medical Education: a Systematic Review. Med Educ. 2010;1(12). WMC001261.

15. Nicholl T, Lou K. A Model for Small-Group ProblemBased Learning in a Large Class Facilitated by One Instructor. American Journal of Pharmaceutical Education. 2012;76(6).

16. Ormrod JE. Human Learning. $5^{\text {th }}$ ed. Pearson International Edition. Pearson Prentice Hall; 2009. 